\title{
Mapping of landslide hazards prediction using geographic information system in Solok District
}

\author{
Abdurrohim ${ }^{1, *}$, Hidayat Firman ${ }^{1}$ \\ ${ }^{1}$ Program of Forestry, Muhammadiyah University of West Sumatera, Padang, Pasir Kandang St, No.4 Koto Tangah Sub \\ District, Padang City
}

\begin{abstract}
Solok District is one of the areas prone to the landslide in West Sumatera Province. Generally, landslides are caused by natural and human factors. The aims of this study are to predict the location of the highest landslide hazard distribution in Solok District and to know the level of vulnerability of landslide hazards in Solok District. This study consists of preparatory steps, field survey, analysis and processing of the data based on 4 types of maps, i.e. rainfall, soil type, geological, and slope maps. These maps then scoring in 5 types of vulnerability levels. As the results of this study, it is known that the sub-districts are on the highest prediction of the landslide are Pantai Cermin, Lembah Gumanti, Hiliran Gumanti, Lake Kembar, Mount Talang, Payung Sekaki, Tigo Lurah, Bukit Sundi, Kubung, X Koto Singkarak and Junjung Sirih. The level of vulnerability prediction of landslide hazard in Solok District is divided into 5 levels, which is very low $44511,71 \mathrm{Ha}$ with percentage of $11,91 \%$, low of $69179,34 \mathrm{Ha}$ with percentage $18,51 \%$, while $89894.35 \mathrm{Ha}$ with the percentage of $24.05 \%$, height of $86307 \mathrm{Ha}$ with the percentage of $23.09 \%$, and very high $83907,60 \mathrm{Ha}$ with the percentage of 22.45 .
\end{abstract}

\section{Introduction}

Natural disasters may be happened anytime and anywhere, which causes material and immaterial losses in people's lives. The landslides are one of the most common natural disasters in mountainous areas, especially in the rainy season. It may result in loss of property and casualties and damage to other facilities and infrastructures such as housing, industry and agricultural land. Further, can affect the social condition of the community and the decline of the economy in the affected areas. The National Disaster Management Agency (2016) reported 2,425 of the landslides in Indonesia during 2011-2015. Most of the landslides occurred in the Central Java, West Java, East Java, West Sumatra, and East Kalimantan provinces. The earthquake caused 1,163 of the dead, 112 people were missing, 973 people injured and 48,191 people displaced.

Solok District is one of the vulnerable landslides areas in West Sumatera Province do to it area has the slope more than $15 \%$ and spread within 306,322 ha or $82 \%$ of the total area of Solok District. In general, the Solok District is close to the fault of the AustronesianAsian plate and located on the active volcano of Indonesia. The location of Solok District then causes this area becomes prone to the earthquakes and landslides. The Solok District dominate by the mountain area, i.e. approximately about 373,800 ha (Warmanto et al. 2007).

In this study, mapping of the landslides events in the landslides prone areas map has been conducted in order to minimize the risk of the landslides. Notting that, it's important to identify the main cause of the landslides including there landslide characteristics. To do this, a computer data-based software of the Geographic Information System (GIS) is required. By using this GIS software, the landslides vulnerability areas can be quickly identified accurately. GIS used to process the land parameters data to define the considered landslides vulnerability. By using this GIS software is expected we may minimize the triggers and the effects of the landslide disaster to the community life around the landslide vulnerability areas.

\section{Research methodology}

This research was conducted in Solok District. The study covered $3,738 \mathrm{~km} 2$ area on the $329 \mathrm{~m}-1,458$ above sea level. The coordinate of the study location is $100^{\circ} 25^{\prime} 00$ "to $101^{\circ} 41^{\prime} 00^{\prime \prime} \mathrm{BT}$ and $00^{\circ} 32^{\prime} 00$ "to $01^{\circ} 46^{\prime} 00^{\prime \prime} \mathrm{LS}$.

Materials needed in the research are:

1. Solok District rainfall data during 2007-2016.

2. Land Map of Solok District Scale 1: 25,000

3. Solok District Administration Map Scale 1: 25,000

4. Geology Map of Solok District Scale 1: 25.000

5. Slope Map of Solok District Scale 1: 25.000

The study has been conducted following the Indonesian Disaster Risk manual (BNPB 2016). Each landslide parameters were calculated and scored based on the BNPB standard. These values furthermore were mapped to the available maps by using ArcGIS 10.1 .

*Corresponding author: abdulrohim_hut@yahoo.co.id 
The parameters of landslide hazard maps based on BNPB 2016 are tabulated in Table 1.

Table 1. Parameters of landslide hazard map preparation

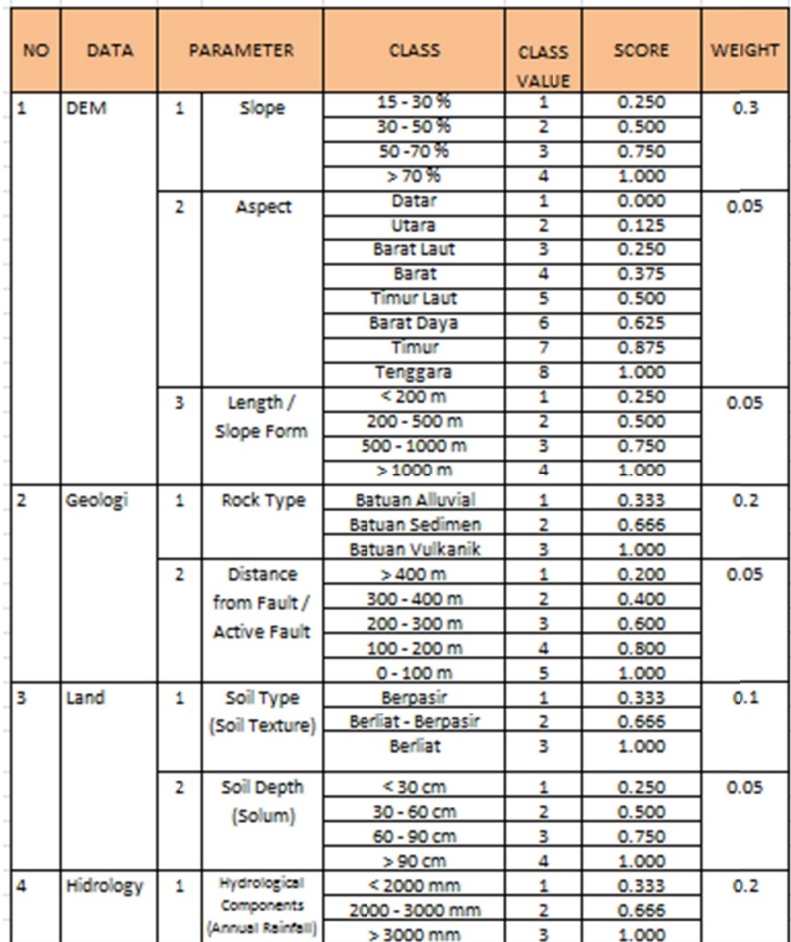

Source: BNPB 2016

The possibility of the occurrence of the landslides is defined by the landslides vulnerability below;

Score $=(40 \% \times$ grade slope $)+(25 \% \times$ geological grade factor $)+(15 \% \times$ soil class type factor $)+(20 \% \times$ rainfall factor)

The scoring marked on the map indicates the spreading of the landslide areas and the level of landslides vulnerability in the Solok District (Fig.2.)

Table 2. the level of landslides vulnerability in the Solok District

\begin{tabular}{|c|c|l|}
\hline $\begin{array}{c}\text { Land Vulnerability } \\
\text { Zone }\end{array}$ & $\begin{array}{c}\text { Class } \\
\text { Value }\end{array}$ & $\begin{array}{l}\text { Hazard } \\
\text { Index }\end{array}$ \\
\hline Very Low & 1 & $\begin{array}{l}\text { Maximum } \\
\text { Class } \\
\text { Value Class } \\
\text { Value }\end{array}$ \\
\hline Low & 2 & \\
\hline Medium & 4 & \\
\hline High & 5 & \\
\hline Very High & 5 \\
\hline
\end{tabular}

Source: BNPB 2016

\section{Result and discussion}

\subsection{The prediction of the landslide location distribution}

The parameters used in this study are the slope of the land, the intensity of the rainfall, geological and soil types. The calculation, in a value of scoring, results in the Prediction Map of Landslide Location Distribution and Map of vulnerability level of the Landslides Hazard Prediction. The prediction of the landslide locations was defined based on vulnerability prediction rate of the landslide hazard. This prediction of the landslide locations for the Solok District is given in Table 3.

Table 3. Predicted locations of landslide distribution in Solok District

\begin{tabular}{|c|c|c|c|}
\hline No & $\begin{array}{l}\text { Predicted Locations } \\
\text { / Sub-District }\end{array}$ & Area $(\mathrm{Ha})$ & $\begin{array}{c}\text { Percentage } \\
(\%)\end{array}$ \\
\hline 1 & Pantai Cermin & 14418,54 & 17,2 \\
\hline 2 & Lembah Gumanti & 26598,44 & 31,7 \\
\hline 3 & Hiliran Gumanti & 5549,41 & 6,6 \\
\hline 4 & Payung Sekaki & 5720,56 & 6,8 \\
\hline 5 & Tigo Lurah & 4412,38 & 5,3 \\
\hline 6 & Lembang Jaya & 3713,51 & 4,4 \\
\hline 7 & Danau Kembar & 5051,76 & 6,0 \\
\hline 8 & Gunung Talang & 13771,31 & 16,4 \\
\hline 9 & Bukit Sundi & 676,58 & 0,8 \\
\hline 10 & Kubung & 1100,15 & 1,3 \\
\hline 11 & X Koto Singkarak & 1493,00 & 1,8 \\
\hline 12 & Junjung Sirih & 1401,65 & 1,7 \\
\hline & Total & 83907,30 & 100 \\
\hline
\end{tabular}

Source: Processing in Arcgis 
The spreading of the highest landslide prediction denotes the area with the high frequency of the landslide events and high level of the landslides vulnerability. The sub-districts where are located on the highest predicted landslide areas are Pantai Cermin District, Lembah Gumanti Sub-district, Hiliran Gumanti Sub-District, Lake Kembar Sub-District, Talang Mountain District, Payung Sekaki Sub-district, Tigo Lurah Sub-district, Bukit Sundi Sub-district, Kubung District, X Koto Singkarak Sub-district, and District Junjung Sirih.

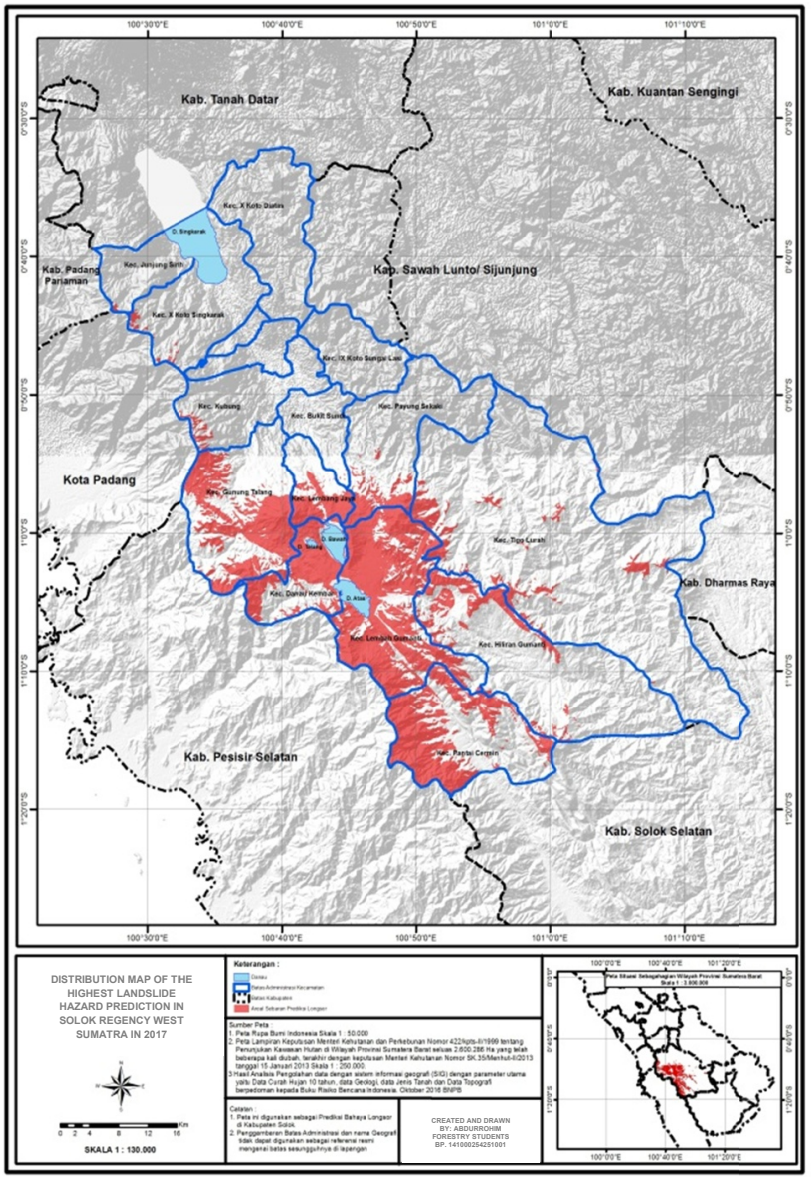

Source: Processing in Arcgis

Fig. 1. Map predicted locations of landslide distribution in Solok District

The spreading of the highest landslide prediction denotes the area with the high frequency of the landslide events and high level of the landslides vulnerability. The sub-districts where are located on the highest predicted landslide areas are Pantai Cermin District, Lembah Gumanti Sub-district, Hiliran Gumanti Sub-District, Lake Kembar Sub-District, Talang Mountain District, Payung Sekaki Sub-district, Tigo Lurah Sub-district, Bukit Sundi Sub-district, Kubung District, X Koto Singkarak Sub-district, and District Junjung Sirih.

The covering area of the landslides prediction in Pantai Cermin, Lembah Gumanti, and Gunung Talang sub-districts are 14418,54 Ha, 26598,44 Ha, and 13771,31, respectively.

However, if calculation based on the percentage of the landslide areas toward to the area of each district, Lembang jaya (66\%) and Danau Kembar (39\%) sub- district occupy the highest position. Eleven District in Solok District became the highest area as the prediction area of landslide spread in Solok District due to several factors:

1) Tilt

The study area is surrounded by fairly steep hills. The area is managed by the forestry department. On the west side is bounded by the National Park (Kerinci Seblat National Park), on the east side is bounded by the Protected Forest Area. Most of the sub-districts in the Solok District have a fairly high gradient, more than $70 \%$, then the high gradient of the slope value triggers a bigger landslide, which will result higher thrust. This steep slope has been formed due to the erosion of river water, springs, sea water, and wind.

2) Geology

Rock types in the study area consist of volcanic rocks (Qv, Kgr, Jsl, Qol, Kub, Tgdr, Qatg, QTWt, and Qf) and Sediment rocks ( $\mathrm{Pbl}, \mathrm{Ps}, \mathrm{Pb})$. Both types of rock are fairly fragile. Rocks will become soil easily when weathered, generally prone to landslides when in steep slopes (Nandi, 2007).

In addition, these twelve sub-districts were traversed by a fault crater. Gunung Talang, Lembang Jaya, and Kembar Lake Sub-districts are next to Gunung Talang. This mountain becomes the administrative boundary of the three districts, so if there is an activity of Mount Talang, it may cause an earthquake, which has the potential of landslide disaster.

According to Sugianti, et al (2014), she said that the geological structural factor in the form of a fault can weaken the strength of the rock, so it becomes prone to landslides. This is because the resulting cracks will become a place of water seepage which reduces the strength of rocks/soil naturally which can eventually produce soil movement.

3) Land

Based on the Land and soil map, made by the Soil Research Center and Agro-climate 1990, the twelve types of soil were mostly Inceptisols. This type of soil is immature soil, still resembling the nature of the base material which has a thick thickness of solum more than 1.5 meters - 10 meters on the main rock with consist of clay texture.

Soil which has a solum depth of more than 1 meter or even thicker can cause saturation due to water infiltration, only a small portion is runoff surface water. As a result of the saturation, due to continuous water intake into the clay, thus making small fractures even bigger, eventually causing landslides (Nandi, 2007)

4) Rainfall

Based on the average rainfall data from 2007 to 2016 in Solok District, the intensity of rainfall in these twelve sub-districts is very high. This phenomenon causes the volume of water increase and make water flowing on steep slopes increasingly suppress soil 
granules and cause surface flow and then the soil slips following the slope path (Nandi, 2007).

\subsection{Determination of landslide resistance level}

\subsubsection{Results}

The vulnerability level of the landslide in Solok District can be seen from Table 4 below.

Table 4. Area of landslide vulnerability

\begin{tabular}{|c|c|c|c|}
\hline No & $\begin{array}{c}\text { Level of } \\
\text { Insecurity }\end{array}$ & $\begin{array}{c}\text { Area } \\
(\mathrm{Ha})\end{array}$ & $\begin{array}{c}\text { Percentage } \\
(\%)\end{array}$ \\
\hline 1 & Very Low & 44511,71 & 11,91 \\
\hline 2 & Low & 69179,34 & 18,51 \\
\hline 3 & Medium & 89894,35 & 24,05 \\
\hline 4 & High & 86307,00 & 23,09 \\
\hline 5 & Very High & 83907,60 & 22,45 \\
\hline & Total & $\mathbf{3 7 3 8 0 0}$ & $\mathbf{1 0 0 , 0 0}$ \\
\hline
\end{tabular}

Source: Processing in ArcGIS

The Prediction of Landslide Vulnerability by District in Solok District can be seen in Fig.2.

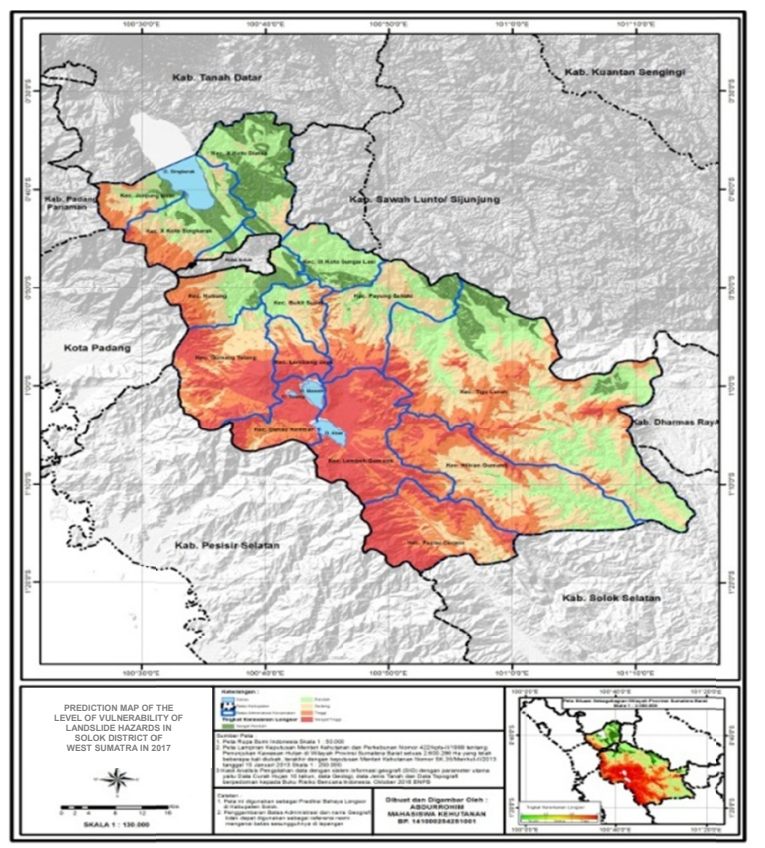

Source: Processing in ArcGIS

Fig. 2. Map of the Distribution of Landslide Flood Rate Prediction per District

The results of the landslide susceptibility analysis were divided into five classes of landslide susceptibility, namely areas with very low, low, medium, high and very high vulnerability, which is based on the results of each parameter of landslide prediction, landslide vulnerability and various areas in Solok District.

1) Very low insecurity
The low landslide susceptibility class is an area with very low vulnerability of landslides. The range slope of this area is $<15 \%$. The probability of landslides in this region is very low, small landslides may occur on river valleys, depending on soil properties, rock formers, land cover and soil movement susceptibility (Fajria, 2016).

Areas with very low landslide vulnerability in Solok District are dominated by alluvial plains, sediments and volcanic plains, dominated by terrain and ramps making this area have long slopes, $>1000$ $\mathrm{m}$. The length of the slope has a large influence on the magnitude of the landslide volume. The slope of a flat slope causes a downward pulling force due to the gravity of the earth so that the flat field has little chance for moving (Arsyad, 2000). Based on data analysis with ArcGIS 10.1 area with very low landslide susceptibility in Solok area covering $44511.71 \mathrm{Ha}(1.91 \%$ of the total administrative area of Solok Regency). Areas with a very low level of vulnerability are more dominant in Northeast and Northwest Solok.

2) Low level of insecurity

Physiographically the shape of the land in this area is not much different from the physiographic form of the area that has very low landslide susceptibility. This region is in the range of slope is $15-30 \%$. The probability of landslides in this region is low (BNPB, 2016).

After processing and spatial analysis with ArcGIS 10.1, the area of low landslide susceptibility is covering $69179,34 \mathrm{Ha} \quad(18,51 \%$ of total administration area of Solok Regency). Areas with low landslide vulnerability lie to the northwest, northeast, and southeast of Solok District.

3) Medium degree of vulnerability

Areas with moderate landslide susceptibility are areas that generally have moderate vulnerability of landslides. Large and small landslides can occur, especially in areas adjacent to river basins, steep cliffs, overhanging cliffs and on disturbed slopes. This region generally has topographic conditions in the slope range of $30-50 \%$. The condition of textured clay (clay) which is a soil that if in wet conditions will occur a high level of saturation, has very strong properties and is almost always compressed. The high level of clay makes it easy for the soil to bind water and find it difficult to get water (Isa Darmawijaya, 167: 1990). The high water content in the clay soil makes the soil easy to move and causes landslides in this area, although the texture of the clay clay is not so steep that it makes this slope class enter the moderate volcanic mud level. The area of landslide susceptibility is 89894.35 Ha or $24.05 \%$ of the total administrative area of Solok Regency which is the most widespread vulnerability compared to the level of other landslide vulnerabilities. Areas that have landslide susceptibility are present in almost all districts in Solok District. 
4) High frequency

Areas that include in high landslide susceptibility classes are areas that generally have a high level of vulnerability to landslides. At a high level of vulnerability, large to very small landslides often occur (Fajria, 2016). This region is in the slope range of $50 \%-70 \%$, covering an area of $86307.00 \mathrm{Ha}$ (23.09\% of the area of Solok Regency). The type of soil in this area is inceptisol soil with textured clay, with hilly hills and scattered in all districts in Solok District, except IX Koto Lasi River and Koto Diatas Sub District Above that are different due to relative slope.

5) Very high insecurity

The area of very high landslide vulnerability is the most potential landslide area, the incident encountered in the field is that the area that is included in the landslide vulnerability is very high, $83907.60 \mathrm{Ha}(22.45 \%$ of the total area of Solok Regency). The very high level of landslide susceptibility is due to the steep slope to very steep $(>70 \%)$ with mountainous landscapes (Sugianti, et.al 2016). The soil types found in the form of Litosol species are found on mountain slopes and hills. The area's land use is plantations and forests. Incepticol soil type is clay textured and has a significant rainfall intensity which is above an average of $>2000 \mathrm{~mm} /$ year. Areas with very high landslide susceptibility are in the South, and Southwest of Solok Regency, Gunung Talang District, Lembang Jaya, Gumanti Valley, Pantai Cermin SubDistrict.

\section{Conclusions}

\subsection{Conclusion}

1) The highest spread of landslide prediction is on slopes $>70 \%$, distance from faults $0-100 \mathrm{~m}$, bulk $>$ $3000 \mathrm{~mm} /$ year and soil texture is also often found landslide configuration. The average Land Size 83907.30 Ha Landslide spread in several districts in Pantai Cermin, Gumanti Valley, Hiliran Gumanti District, Kembar Lake, Gunung Talang, Payung Sekaki, Tigo Lurah, Bukit Sundi, Kubung, District $\mathrm{X}$ Koto Singkarak, and Junjung Sirih SubDistric.

2) The level of vulnerability resulting from the landslide hazard prediction in Solok Regency was divided into 5 levels, namely very low, 44511.71 Ha (1.91\%), low, 69179.34 Ha (18.51\%), moderate, 89894.35 На (24.05\%), high, 86307 На (23.09\%), and very high at $83907.60 \mathrm{Ha},(22.45 \%)$.

\subsection{Recommendation}

Other methods should be used for further mapping of soil hazards to identify more detailed vulnerabilities and landslides. In order people understand regarding the dangers of landslides, dissemination of information in the form of booklets, early warning posters of landslides.

\section{References}

1. Arsyad, S, Soil and Water Conservation. Bandung: IPB Publisher (2000) (IPB Press).

2. BNPB. Indonesian Disaster Risk. Jakarta. BNPB (2016)

3. Ministry of Energy and Mineral Resources. 2005. Introduction to the Land Movement, Vulcanological Survey of Indonesia. Energy Mineral Resources. Jakarta.

4. Public Works Department. Spatial Planning Guidance for Landslide Prone Areas. Directorate of Spatial Planning. Jakarta (2007)

5. West Sumatra Provincial Forestry Service. Shapefile Land, Geology, Slope data. West Sumatra Provincial Forestry Service. Padang (2017)

6. Directorate of Environmental Geology. Land Movement in Indonesia. Directorate General of General Mining. Department of Mines and Energy. Jakarta (1981)

7. [DIRJENPLANHUT] Directorate General of Forestry Planning. Regulation of the Director General of Forestry Planning No. P.3/VIIIPSDH/2014, Technical Guidelines for Drawing and Presenting Forestry Maps. DIRJEN Forestry Planning, Jakarta (2014)

8. Fajria L. Measuring Landslide Vulnerability At Sub-District Of Prambanan, Region Of Sleman Using Geographic Information System. Yogyakarta. Universitas Negeri Yogyakarta (2016)

9. $\quad$ Fajria L.. Measuring Landslide Vulnerability At Sub-District Of Prambanan, Region Of Sleman Using Geographic Information System. Yogyakarta. Universitas Negeri Yogyakarta (2016)

10. Karlina. I.I. Analysis of Landslide Vulnerability Level in Part of Class IIIC Road in Gesing Sub-District, Purworejo District, Central Java. Disaster Research Journal, Indonesia Vol. 2 No. 1, May 2016 : 40-49 (2016)

11. KPHL Model Solok Unit VI. Long Term Forest Management Plan (RPHJP) Protected Forest Management Unit (KPHL) Solok District Model 2014-2023. Solok District Forestry and Plantation Service, Solok (2013)

12. Mardikaningsih. S. M. et, al. Study of Vulnerability and Direction of Flood Disaster Mitigation in Puring District, Kebumen Regency. Journal GeoEco ISSN:2460-0768., 
Vol. 3, No. 2 (Juli 2017) Hal. 157-163 (2016)

13. Minister of Public Works. Regulation of the

Minister of Public Works No: 22/PRT/M/2007, Guidelines for Spatial Planning for Landslide Prone Areas. public Works Department, Jakarta (2007)

14. Nandi. Landslide. Bandung: Department of Geography Education, University of Indonesia Education (UPI) (2007)

15. Sudibyakto. Et, al. Disaster Risk Management in the Padang Ciamis Mountain Heritage Area, West Java. Indonesian Disaster Research Journal Vol. 2 No. 1, May 2016 : 50-58 (2016)

16. Sugianti. K. et, al. Classification of Ground Movement Vulnerability of South Sumedang Area using Storie Method. Journal of the LIPI Geotechnology Research Center. (Ris.Geo.Tam Vol. 24, No.2, Desember 2014 (93-104) (2014)

17. Hidayat. R. et, al. Landslide Handling on Gempol - Pandaan Toll Road Slope Km 51 Pasuruan East Java. Indonesian Disaster Research Journal, Vol.1 No.2, Oktober 2015 : 15-22.( 2015)

18. Aminatun. S. 2015. Implementation of Resettlement Relocation Policy on Landslide Threats (Case Study of Srimartani Village, Piyungan District, Bantul Regency, Yogyakarta Special Region). Indonesian Disaster Research Journal Vol.1 No.2, 13 October $2015:$ 23-31. 